Article

\title{
Eco-Friendly Nets and Floating Row Covers Reduce Pest Infestation and Improve Tomato (Solanum lycopersicum L.) Yields for Smallholder Farmers in Kenya
}

Elisha O. Gogo ${ }^{1}$, Mwanarusi Saidi ${ }^{1}$, Francis M. Itulya ${ }^{1}$, Thibaud Martin ${ }^{2,3}$ and Mathieu Ngouajio ${ }^{4,5}, *$

1 Department of Crops, Horticulture and Soils, Egerton University, P.O. Box 536, Egerton 20115, Kenya; E-Mails: elishaotieno41@yahoo.com (E.O.G.); mwanarusi@yahoo.com (M.S.); fitulya@hotmail.com (F.M.I.)

2 CIRAD (Centre de coopération internationale en recherché agronomique pour le développement) UR Hortsys, Avenue Agropolis, Montpellier Cedex 5 34398, France; E-Mail: thibaud.martin@cirad.fr

3 Icipe, Plant health Department, P.O. Box 30772, Nairobi 00100, Kenya

4 Department of Horticulture, Michigan State University, 1066 Bogue Street, Plant and Soil Science Building, East Lansing, MI 48824, USA

5 National Institute of Food and Agriculture (NIFA), Washington, DC 20250, USA

* Author to whom correspondence should be addressed; E-Mail: mngouajio@nifa.usda.gov; Tel.: +1-202-401-4895; Fax: +1-202-401-6488.

Received: 19 November 2013; in revised form: 27 December 2013 / Accepted: 2 January 2014 / Published: 9 January 2014

\begin{abstract}
Tomato (Solanum lycopersicum L.) is an important vegetable for supplying vitamins, minerals and fiber in human diets worldwide. Successful open field production of tomato in the tropics is limited by insect pests among other constraints. Two trials were conducted at the Horticulture Research and Teaching Field, Egerton University, Kenya with the objective of evaluating the effects of agricultural nets (agronets) herein called eco-friendly nets (EFNs) and floating row covers (FRCs) on pest population and yield of tomatoes. A randomized complete block design with five replications was used. Tomato plants were protected with either fine mesh EFN (0.4-mm pore diameter), large mesh EFN (0.9-mm pore diameter) or FRC. The EFN and FRC were maintained permanently closed or opened thrice a week from 9 am to $3 \mathrm{pm}$. Two control treatments were used: open unsprayed (untreated control) or open and sprayed with alpha-cypermethrin based insecticide (treated control). The use of EFN and FRC helped to manage pests with the
\end{abstract}


lowest pest population obtained under FRC maintained permanently covered and the highest population recorded in the untreated control. Covering tomato plants with EFN or FRC also resulted in more marketable fruit and lower yield losses compared with the unprotected systems. The EFN and FRC offer great potential as part of integrated systems for pest management and yield improvement in tomato production in regions with a tropical climate.

Keywords: pest exclusion; pest control; tomato yields; tomato quality; microclimate modification

\section{Introduction}

Tomato (Solanum lycopersicum L.) production is one of the most promising areas for horticultural expansion and development in many developing countries. The crop is an important vegetable for both small and medium-scale growers with a potential for increasing income and creating employment. Fresh tomatoes are produced for both domestic and export market in most developing countries, and there is increasing demand for processing. Increased production of tomato may improve living standards, especially in rural areas of many developing countries where poverty is prevalent [1].

In many tropical countries, successful tomato production is constrained by pest infestations that contribute to reduced fruit yield and quality $[2,3]$. Common pests of tomato in the tropics include leafminers (Lyriomyza sp.), cotton bollworms (Helicoverpa armigera Hubner), onion thrips (Thrips tabaci Lindeman), mites (Tetranychus sp.), silverleaf whitefies (Bemisia tabaci Gennadius), and aphids (Aphis sp.) [3]. Yield losses as high as 100\% due to insect pest damage have been reported [2]. Although a wide range of pesticides exists in the pest control industry, growing public awareness and concern for the adverse effects of these chemicals on human health, soil, and water resources demand that producers rethink their pest management options. Moreover, the development of resistance among most pests following repeated use of certain chemicals provides an opportunity to look for eco-friendly, safer, and sustainable methods of pest control.

Use of eco-friendly nets (EFNs) in protected cultivation was tested in Africa [4] and proved effective against many pests on cabbage (Brassica oleracea L. var. capitata L.). Floating row covers (FRCs) as an effective pest management tool against various insect pests, including aphids, cucumber beetles (Acalymma and Diabrotica sp.), whiteflies, and their related pathogens has also been on the increase due to their demonstrated ability to serve as a physical barrier against pests [5-7]. As a result of pest exclusion, covers present a potential for reducing pesticide application in any given crop, thus providing a more environmentally friendly alternative for controlling insect pests among small-holding farmers $[4,8,9]$.

The use of covers in crop production also has a direct impact on plant growth and development resulting in better yield [10,11]. In Kenya, EFNs have successfully been used to reduce insect pests and improve tomato and cabbage transplant production [12,13]. According to Licciardi et al. [8], mesh size of the cover used can affect insect penetration and microclimate around the crop. While many studies have reported positive effects on yield with the use of net covers [4,10], Joubert et al. [14] 
observed low yields in protected tomato during summer in France as a result of high heat accumulation, based on which, they recommended periodic opening of the structure during the day time in such situations. The current study aimed at investigating the effects of EFNs of different pore diameters and FRCs managed by maintaining them either permanently covered or opened thrice a week on the population of major tomato pests and fruit yield under tropical conditions.

\section{Materials and Methods}

\subsection{Experimental Site}

Two trials (May to October 2011 and October 2011 to March 2012) were conducted at the Horticulture Research and Teaching Field of Egerton University, Njoro, Kenya. The field lies at a latitude of $0^{\circ} 23^{\prime} \mathrm{S}$ and longitude $35^{\circ} 35^{\prime} \mathrm{E}$ in the Lower Highland III Agro Ecological Zone (LH3) at an altitude of $\sim 2238 \mathrm{~m}$ above sea level. The average maximum and minimum temperatures for the growing seasons was $19.5^{\circ} \mathrm{C}$ and $7{ }^{\circ} \mathrm{C}$ for season 1 , and $21{ }^{\circ} \mathrm{C}$ and $10{ }^{\circ} \mathrm{C}$ for season 2 , respectively, with a mean total annual rainfall of $1400 \mathrm{~mm}$ in season 1 and $1000 \mathrm{~mm}$ in season 2. Soils are predominantly andosols with a $\mathrm{pH}$ of $6.0-6.5$ [15].

\subsection{Planting Material, Experimental Design, and Treatments}

"Rio Grande" tomato transplants were started under an eco-friendly net covered nursery to ensure that they were of superior quality and virus free. The experiment was laid in a randomized complete block design (RCBD) with five replications. Transplants were established under eight different treatments as follows: (i) open unsprayed (untreated control); (ii) open sprayed with alpha-cypermethrin based insecticide on a weekly interval (treated control); (iii) FRC maintained permanently covered; (iv) fine mesh (0.4-mm pore diameter) EFN maintained permanently covered; (v) large mesh (0.9-mm pore diameter) EFN maintained permanently covered; (vi) FRC opened three times a week from 9:00 am to 3:00 pm; (vii) fine mesh (0.4-mm pore diameter) EFN opened three times a week from 9:00 am to 3:00 pm; and (viii) large mesh (0.9-mm pore diameter) EFN opened three times a week from 9:00 am to 3:00 pm. Row covers used were manufactured by Agribon, Mooreville, NC while the EFN were manufacture by A to Z Textile Mills, Arusha, Tanzania. Each block measured $71 \times 1-\mathrm{m}$ separated by a 1 -m buffer. Within each block, individual experimental units measured $8 \times 1-\mathrm{m}$ separated by a $0.5-\mathrm{m}$ buffer. In every plot, three posts $1.2-\mathrm{m}$ long were placed $4-\mathrm{m}$ apart along the $8-\mathrm{m}$ bed to serve as a support system for the cover and the crop. The posts were grounded $20-\mathrm{cm}$ deep for appropriate support. Binding wires were then pinned at $30-\mathrm{cm}$ intervals from the ground to the top of the posts to complete the crop support system. Additionally, for the covered treatments, ordinary mild steel (R6) 1-m long pieces were mounted on top of each post, fastened using U-nail and bent to provide a tunnel shape for dressing the covers. Covers used on each experimental unit measured 3-m wide and 11-m long.

\subsection{Land Preparation and Maintenance Practices}

The field was ploughed to a $\sim 20 \mathrm{~cm}$ depth and later harrowed to a fine tilth using a disc plough and harrow, respectively. One week before transplanting, tomato seedlings were hardened off by reducing watering frequency to only once at the beginning of the week. Transplanting holes were manually dug 
using a hoe and diammonium phosphate $\left(18 \% \mathrm{~N}, 46 \% \mathrm{P}_{2} \mathrm{O}_{5}\right)$ applied at 10 g per hole and thoroughly mixed with the soil prior to transplanting. Four-week-old tomato seedlings were transplanted in one row $8 \mathrm{~m}$ long and at $50 \mathrm{~cm}$ within the row [16] giving 16 tomato plants per experimental unit. Before covering the plots with EFN and FRC, all plots were given blanket spray of insecticide (alpha-cypermethrin $100 \mathrm{~g} / \mathrm{L} \mathrm{EC}$ ) at the rate of $25 \mathrm{~mL} / 20 \mathrm{~L}$ of water provided by Orbit Chemical Industries LTD., Nairobi, Kenya. This was to avoid trapping insects inside the covers at the beginning of the experiments. Thereafter, standard good agricultural practices including fertilizer application, watering, weeding and training were done uniformly on all experimental units on a need basis.

\subsection{Data Collection}

Data for all variables were collected from the middle 14 plants in all the experimental units.

Pest Count: Weeds were counted from an area of $1 \mathrm{~m}^{2}$ at the center of each experimental unit prior to each weeding. The numbers of insect pests at their respective injurious stage(s) were counted once every week. Counting of insects was done early in the morning when most insects had low activity. Hand lenses (G-888-075; Shanghai Precision and Scientific Instrument Co., Shanghai, China) were used for counting smaller pests like mites, thrips and aphids. During weed and insect assessments, the opening of the EFN and FRC was minimal for treatments requiring a permanent protection.

Yield: Harvesting of fruit at the pink stage was done weekly for four weeks. At each harvest, the total fruit number and weight was recorded. Fruit was sorted into marketable and non-marketable based on the market standard that prevailed and their numbers and weight determined. The total and non-marketable fruit yields were then used to compute the percent yield loss.

\subsection{Data Analysis}

The Proc univariate procedure of SAS (version 9.1; SAS Institute, Cary, NC, USA) was used to check for normality of the data before analysis. Data were then subjected to analysis of variance (ANOVA) using the GLM at $p \leq 0.05$. Data for the two seasons were pooled together and analyzed using the statistical model: $Y i j=\mu+\beta i+\alpha j+\varepsilon i j$ where; Yij is the tomato yield response, $\mu$ is the overall mean, $\beta i$ is the $i$ th blocking effect, $\alpha j$ is the effect due to the $j$ th treatment and $\varepsilon i j$ is the random error term. Means for significant treatments, at the F test, were separated using Tukey's honestly significant difference (THSD) test at $p \leq 0.05$.

\section{Results}

\subsection{Weed Population}

The most prominent weeds observed were oxalis (Oxalis latifolia Kunth), blackjack (Bidens pilosa L.), and gallant soldier (Galinsoga parviflora Cavanilles). The weed population was influenced by the use of EFN and FRC. Higher weed populations were recorded under EFN and FRC compared with the open field treatments during early stages of tomato growth as shown in Figure 1. The highest weed population was recorded under the FRC maintained permanently covered in most of the early stages of tomato growth. The weed population trend, however, changed as time from transplanting advanced. Throughout the mid and late stages of the crop, more weeds were observed under the open field 
treatments compared with EFN and FRC treatments, with the lowest weed population recorded under the FRC that stayed permanently covered. Averaged over the entire study period, open field treatments had the highest weed population while FRC maintained permanently covered had the lowest population (Figure 2). Among other covered treatments, FRC opened thrice a week had the lowest weed population followed by 0.4-mm EFN maintained permanently covered, 0.4-mm EFN opened thrice a week, 0.9-mm EFN maintained permanently covered, and highest under the 0.9-mm EFN opened thrice a week.

\subsection{Insect Pest Population}

The numbers of leafminers, cotton bollworms, onion thrips, mites, silverleaf whiteflies, aphids on the tomato crop were significantly reduced by the use of EFN and FRC in both seasons (Table 1). In all sampling dates, the highest population of each pest was observed under the untreated control treatment. Pest populations were among the lowest under FRC maintained permanently covered being significantly lower than the pest populations recorded for the treated control treatment in most sampling dates. Among other treatments, 0.4-mm EFN maintained permanently covered had also a reduced population of the individual pest species followed by the treated control.

\subsection{Yield}

Total Fruit Yield: Growing tomato under EFN and FRC significantly increased tomato total fruit yield (Table 2). The use of FRC maintained permanently covered resulted in the highest total number of fruit while the lowest number was obtained from the unprotected plants sprayed with insecticide and the $0.9-\mathrm{mm}$ EFN maintained permanently covered. In terms of total fresh weight, FRC maintained permanently covered registered the highest total fresh fruit weight while the untreated control had the lowest fruit fresh weight (Table 3). The impact of the treatments on total fruit number was generally minimal.

Marketable Yields: The number of marketable fruit was influenced by the use of EFN and FRC (Table 2). Tomato under FRC maintained permanently covered yielded the highest number of marketable fruit. The lowest number of marketable fruit was, on the other hand, obtained from the untreated control. A trend similar to that of total marketable fruit numbers was observed for marketable fresh fruit weight (Table 3). The highest marketable fresh fruit weight was obtained under FRC permanently covered while the lowest was under the untreated control.

Non-Marketable Yields: The highest non-marketable fruit numbers were obtained from the untreated control and the lowest non-marketable fruit numbers were obtained with the use of FRC maintained permanently covered. The effect of FRC or EFN on non-marketable fresh weight showed a trend almost similar to that of non-marketable fruit numbers with the highest and lowest fresh weights obtained under the untreated control and the FRC maintained permanently covered treatments, respectively (Table 3 ). 
Figure 1. Effects of floating row covers (FRC) and eco-friendly nets (EFN) on weed population trends during tomato production. Values shown are averages for two growing seasons (May to October 2011 and October 2011 to March 2012). Data points within the same date with no letter or the same letter are not significantly different at $p \leq 0.05$. Untreated control had no pesticide applied, treated control was sprayed with pesticides, permanent is where the FRC or EFN were covered throughout except during crop maintenance periods, and opened is where the FRC or EFN were opened thrice a week from 9:00 am to 3:00 pm.

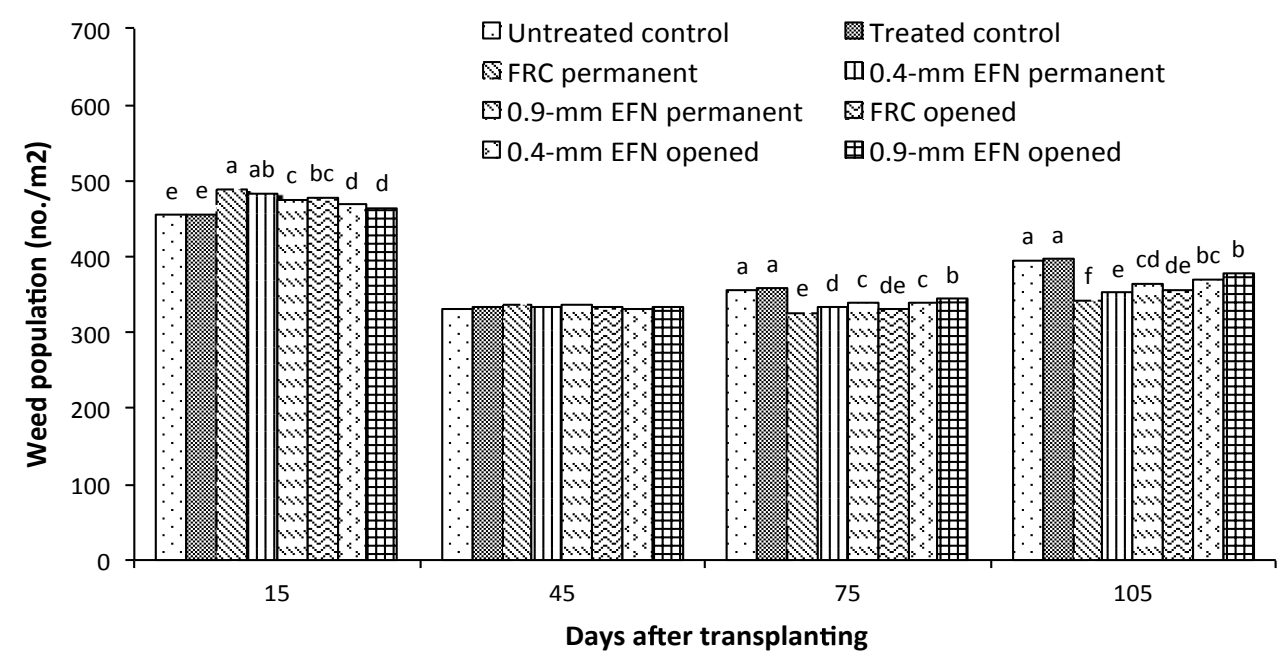

Figure 2. Effects of floating row covers (FRC) and eco-friendly nets (EFN) on mean weed population during tomato production. Values shown are averages for two growing seasons (May to October 2011 and October 2011 to March 2012). Bars having the same letter are not significantly different according to Tukey's honest significant difference (THSD) at $p \leq 0.05$. Untreated control had no pesticide applied, treated control was sprayed with pesticides, permanent is where the FRC or EFN were covered throughout except during crop maintenance periods, and opened is where the FRC or EFN were opened thrice a week from 9:00 am to 3:00 pm.

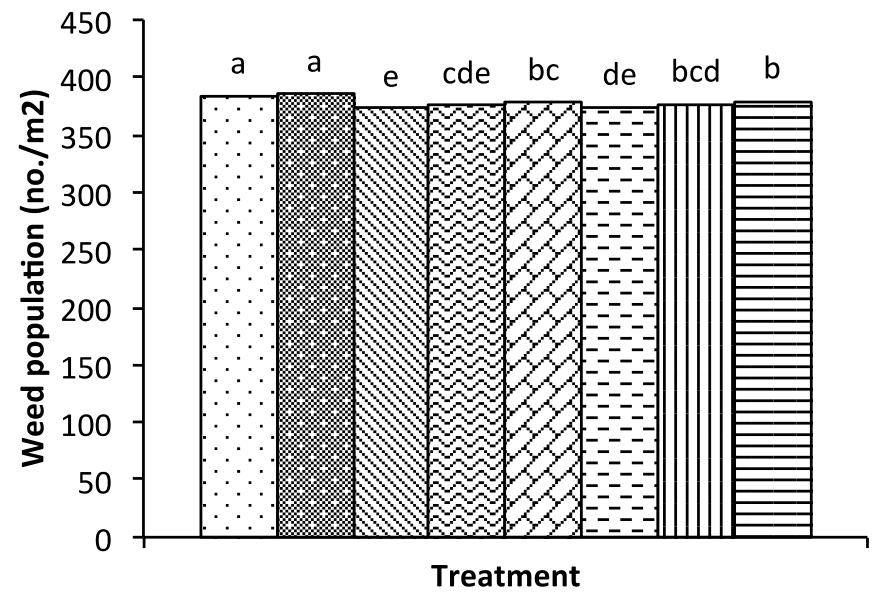

$\square$ Untreated control

Treated control

SFRC permanent

D0.4-mm EFN permanent

๑0.9-mm EFN permanent

EFRC opened

$\square$ 0.4-mm EFN opened

日0.9-mm EFN opened 
Table 1. Effects of floating row covers (FRC) and eco-friendly nets (EFN) on pest population during production of tomato in season 1 (May to October 2011) and 2 (October 2011 to March 2012).

\begin{tabular}{|c|c|c|c|c|c|c|c|c|c|c|c|c|}
\hline \multirow[t]{2}{*}{ Treatment $*$} & \multicolumn{2}{|c|}{$\begin{array}{c}\text { Leafminers } \\
\text { (no./plant) DAT ** }\end{array}$} & \multicolumn{2}{|c|}{$\begin{array}{c}\text { Cotton bollworms } \\
\text { (no./plant) DAT }\end{array}$} & \multicolumn{2}{|c|}{$\begin{array}{c}\text { Onion thrips } \\
\text { (no./plant) DAT }\end{array}$} & \multicolumn{2}{|c|}{$\begin{array}{c}\text { Mites } \\
\text { (no./plant) DAT }\end{array}$} & \multicolumn{2}{|c|}{$\begin{array}{c}\text { Silverleaf whiteflies } \\
\text { (no./plant) DAT } \\
\end{array}$} & \multicolumn{2}{|c|}{$\begin{array}{c}\text { Aphids } \\
\text { (no./plant) DAT }\end{array}$} \\
\hline & 30 & 93 & 30 & 93 & 30 & 93 & 30 & 93 & 30 & 93 & 30 & 93 \\
\hline & \multicolumn{12}{|c|}{ Season one } \\
\hline Untreated control & $0.64 \mathrm{a} * * *$ & $2.64 \mathrm{a}$ & $0.39 \mathrm{ab}$ & $3.00 \mathrm{a}$ & $0.61 \mathrm{a}$ & $3.53 \mathrm{a}$ & $0.70 \mathrm{a}$ & $6.84 \mathrm{a}$ & $2.81 \mathrm{a}$ & $8.13 \mathrm{a}$ & $4.07 \mathrm{a}$ & $9.00 \mathrm{a}$ \\
\hline Treated control & $0.13 \mathrm{c}$ & $0.20 \mathrm{~b}$ & $0.14 \mathrm{~cd}$ & $0.18 \mathrm{~b}$ & $0.30 \mathrm{bc}$ & $0.29 \mathrm{~b}$ & 0.24 cde & $0.23 \mathrm{~b}$ & $0.44 \mathrm{~cd}$ & $0.24 \mathrm{~b}$ & $0.46 \mathrm{~cd}$ & $0.24 \mathrm{~b}$ \\
\hline FRC permanent & $0.14 \mathrm{c}$ & $0.10 \mathrm{~b}$ & $0.14 \mathrm{~cd}$ & $0.16 b$ & $0.13 \mathrm{c}$ & $0.17 \mathrm{~b}$ & $0.13 \mathrm{e}$ & $0.16 \mathrm{~b}$ & $0.14 \mathrm{~d}$ & $0.13 \mathrm{~b}$ & $0.18 \mathrm{~d}$ & $0.16 \mathrm{~b}$ \\
\hline 0.4-mm EFN permanent & $0.11 \mathrm{c}$ & $0.17 \mathrm{~b}$ & $0.10 \mathrm{~d}$ & $0.14 \mathrm{~b}$ & $0.13 \mathrm{c}$ & $0.11 \mathrm{~b}$ & $0.17 \mathrm{e}$ & $0.29 \mathrm{~b}$ & $0.27 \mathrm{~d}$ & $0.35 \mathrm{~b}$ & $0.46 \mathrm{~cd}$ & $0.37 \mathrm{~b}$ \\
\hline 0.9-mm EFN permanent & $0.23 \mathrm{bc}$ & $0.36 \mathrm{~b}$ & $0.27 \mathrm{bc}$ & $0.35 \mathrm{~b}$ & $0.30 \mathrm{c}$ & $0.40 \mathrm{~b}$ & $0.43 \mathrm{bc}$ & $0.39 \mathrm{~b}$ & $0.93 \mathrm{bc}$ & $0.50 \mathrm{~b}$ & $0.81 \mathrm{bc}$ & $0.46 \mathrm{~b}$ \\
\hline FRC opened & $0.37 \mathrm{~b}$ & $0.24 \mathrm{~b}$ & $0.36 \mathrm{ab}$ & $0.21 \mathrm{~b}$ & $0.33 \mathrm{~b}$ & $0.33 \mathrm{~b}$ & $0.33 \mathrm{~cd}$ & $0.36 \mathrm{~b}$ & $0.62 \mathrm{bcd}$ & $0.36 \mathrm{~b}$ & $0.44 \mathrm{~cd}$ & $0.30 \mathrm{~b}$ \\
\hline 0.4-mm EFN opened & $0.27 \mathrm{bc}$ & $0.33 \mathrm{~b}$ & $0.32 \mathrm{ab}$ & $0.35 \mathrm{~b}$ & $0.58 \mathrm{a}$ & $0.42 \mathrm{~b}$ & $0.63 \mathrm{ab}$ & $0.35 \mathrm{~b}$ & $0.58 \mathrm{bcd}$ & $0.64 \mathrm{~b}$ & $0.9 \mathrm{bc}$ & $0.47 \mathrm{~b}$ \\
\hline \multirow[t]{2}{*}{ 0.9-mm EFN opened } & $0.35 \mathrm{~b}$ & $0.36 \mathrm{~b}$ & $0.46 \mathrm{a}$ & $0.33 \mathrm{~b}$ & $0.53 \mathrm{a}$ & $0.42 \mathrm{~b}$ & $0.64 \mathrm{a}$ & $0.40 \mathrm{~b}$ & $1.04 \mathrm{~b}$ & $0.60 \mathrm{~b}$ & $0.93 \mathrm{~b}$ & $0.58 \mathrm{~b}$ \\
\hline & \multicolumn{12}{|c|}{ Season two } \\
\hline Untreated control & $0.66 \mathrm{a}$ & $2.31 \mathrm{a}$ & $0.49 \mathrm{a}$ & $2.42 \mathrm{a}$ & $0.74 \mathrm{a}$ & $3.36 \mathrm{a}$ & $0.84 \mathrm{a}$ & $5.57 \mathrm{a}$ & $2.73 \mathrm{a}$ & $6.56 \mathrm{a}$ & $3.60 \mathrm{a}$ & $9.30 \mathrm{a}$ \\
\hline Treated control & 0.30 cde & $0.31 \mathrm{bc}$ & $0.24 \mathrm{bc}$ & $0.49 \mathrm{~cd}$ & $0.37 \mathrm{bc}$ & $0.34 \mathrm{bc}$ & $0.36 \mathrm{bc}$ & $0.40 \mathrm{~cd}$ & $0.60 \mathrm{~d}$ & $0.57 \mathrm{~cd}$ & $0.50 \mathrm{c}$ & $0.39 \mathrm{de}$ \\
\hline FRC permanent & $0.13 \mathrm{f}$ & $0.11 \mathrm{c}$ & $0.11 \mathrm{~cd}$ & $0.11 \mathrm{f}$ & $0.17 \mathrm{~d}$ & $0.14 \mathrm{c}$ & $0.14 \mathrm{c}$ & $0.17 \mathrm{e}$ & $0.20 \mathrm{f}$ & $0.23 \mathrm{e}$ & $0.23 \mathrm{e}$ & $0.23 \mathrm{e}$ \\
\hline 0.4-mm EFN permanent & 0.14 ef & $0.16 \mathrm{c}$ & $0.10 \mathrm{~d}$ & $0.20 \mathrm{ef}$ & $0.23 \mathrm{~cd}$ & $0.18 \mathrm{c}$ & $0.17 \mathrm{c}$ & $0.29 \mathrm{de}$ & $0.46 \mathrm{e}$ & $0.40 \mathrm{de}$ & $0.29 \mathrm{de}$ & $0.33 \mathrm{de}$ \\
\hline 0.9-mm EFN permanent & $0.23 \mathrm{def}$ & $0.33 \mathrm{bc}$ & $0.26 \mathrm{~b}$ & $0.37 \mathrm{de}$ & $0.37 \mathrm{bc}$ & $0.33 \mathrm{bc}$ & $0.42 \mathrm{~b}$ & $0.42 \mathrm{~cd}$ & $1.27 \mathrm{c}$ & $0.57 \mathrm{~cd}$ & $0.53 \mathrm{bc}$ & $0.50 \mathrm{~cd}$ \\
\hline FRC opened & $0.40 \mathrm{bc}$ & $0.30 \mathrm{bc}$ & $0.36 \mathrm{ab}$ & $0.47 \mathrm{~cd}$ & $0.33 \mathrm{~cd}$ & $0.37 \mathrm{bc}$ & $0.34 \mathrm{bc}$ & $0.40 \mathrm{~cd}$ & $0.57 \mathrm{de}$ & $0.54 \mathrm{~cd}$ & $0.44 \mathrm{~cd}$ & $0.42 \mathrm{de}$ \\
\hline 0.4-mm EFN opened & $0.36 \mathrm{bcd}$ & $0.46 \mathrm{~b}$ & $0.34 \mathrm{ab}$ & $0.64 \mathrm{bc}$ & $0.61 \mathrm{a}$ & $0.46 \mathrm{~b}$ & $0.67 \mathrm{a}$ & $0.51 \mathrm{bc}$ & $1.33 \mathrm{c}$ & $0.71 \mathrm{bc}$ & $0.63 \mathrm{bc}$ & $0.68 \mathrm{bc}$ \\
\hline 0.9-mm EFN opened & $0.47 \mathrm{~b}$ & $0.51 \mathrm{~b}$ & $0.43 \mathrm{a}$ & $0.74 \mathrm{~b}$ & $0.56 \mathrm{ab}$ & $0.50 \mathrm{~b}$ & $0.76 \mathrm{a}$ & $0.58 \mathrm{~b}$ & $1.65 \mathrm{~b}$ & $0.83 \mathrm{~b}$ & $0.71 \mathrm{~b}$ & $0.73 \mathrm{~b}$ \\
\hline
\end{tabular}

* Untreated control had no pesticide, treated control was sprayed with pesticides, permanent is where the FRC or EFN were covered throughout except during crop maintenance periods and opened is where the FRC or EFN were opened thrice a week from 9:00 am to 3:00 pm; ** DAT represents Days after transplanting with 30 and 93 DAT representing mid vegetative and reproductive stages, respectively; *** Means followed by the same letter within a column, a variable and a season are not significantly different according to Tukey's honest significant difference (THSD) at $p \leq 0.05$. 
Table 2. Effects of floating row covers (FRC) and eco-friendly nets (EFN) on tomato yield (no./plant) during production. Values are averages of two growing seasons (May to October 2011 and October 2011 to March 2012).

\begin{tabular}{|c|c|c|c|c|}
\hline Treatment * & $\begin{array}{c}\text { Total fruit number } \\
\text { (no./plant) }\end{array}$ & $\begin{array}{c}\text { Marketable fruit } \\
\text { number (no./plant) }\end{array}$ & $\begin{array}{c}\text { Non-marketable fruit } \\
\text { number (no./plant) }\end{array}$ & $\begin{array}{c}\% \text { Yield loss } \\
\text { per plant } \\
\end{array}$ \\
\hline Untreated control & $20.6 \mathrm{bc} * *$ & $15.9 \mathrm{e}$ & $4.7 \mathrm{a}$ & $22.8 \mathrm{a}$ \\
\hline Treated control & $19.4 \mathrm{e}$ & $17.7 \mathrm{~d}$ & $1.7 \mathrm{c}$ & $8.8 \mathrm{c}$ \\
\hline FRC permanent & $21.5 \mathrm{a}$ & $21.0 \mathrm{a}$ & $0.5 \mathrm{f}$ & $2.3 \mathrm{~g}$ \\
\hline $\begin{array}{c}\text { 0.4-mm } \\
\text { EFN permanent }\end{array}$ & $20.3 \mathrm{c}$ & $19.5 \mathrm{~b}$ & $0.8 \mathrm{e}$ & $3.9 \mathrm{f}$ \\
\hline $\begin{array}{c}0.9-\mathrm{mm} \\
\text { EFN permanent }\end{array}$ & $19.4 \mathrm{e}$ & $17.9 \mathrm{~cd}$ & $1.4 \mathrm{~d}$ & $7.2 \mathrm{~d}$ \\
\hline FRC opened & $21.3 \mathrm{ab}$ & $20.0 \mathrm{~b}$ & $1.3 \mathrm{~d}$ & $6.1 \mathrm{e}$ \\
\hline $\begin{array}{c}0.4-\mathrm{mm} \\
\text { EFN opened }\end{array}$ & $20.2 \mathrm{~cd}$ & $18.4 \mathrm{c}$ & $1.8 \mathrm{c}$ & $8.9 \mathrm{c}$ \\
\hline $\begin{array}{c}0.9-\mathrm{mm} \\
\text { EFN opened }\end{array}$ & $19.5 \mathrm{de}$ & $17.4 \mathrm{~d}$ & $2.1 \mathrm{~b}$ & $10.7 \mathrm{~b}$ \\
\hline
\end{tabular}

* Untreated control had no pesticide, treated control was sprayed with pesticides, permanent is where the FRC or EFN were covered throughout except during crop maintenance periods and opened is where the FRC or EFN were opened thrice a week from 9:00 am to 3:00 pm; ** Means followed by the same letter within a column and a variable are not significantly different according to Tukey's honest significant difference (THSD) at $p \leq 0.05$.

Table 3. Effects of floating row covers (FRC) and eco-friendly nets (EFN) on tomato yield (kg/plant) during production. Values are averages of two growing seasons (May to October 2011 and October 2011 to March 2012).

\begin{tabular}{ccccc}
\hline Treatment $*$ & $\begin{array}{c}\text { Total fresh } \\
\text { weight } \\
\text { (kg/plant) }\end{array}$ & $\begin{array}{c}\text { Marketable fruit } \\
\text { weight (kg/plant) }\end{array}$ & $\begin{array}{c}\text { Non-marketable } \\
\text { fruit weight } \\
\text { (kg/plant) }\end{array}$ & $\begin{array}{c}\text { \% Yield loss } \\
\text { per plant }\end{array}$ \\
\hline Untreated control & $1.9 \mathrm{~g} * *$ & $1.5 \mathrm{f}$ & $0.44 \mathrm{a}$ & $21.1 \mathrm{a}$ \\
Treated control & $2.2 \mathrm{f}$ & $2.0 \mathrm{e}$ & $0.19 \mathrm{c}$ & $9.1 \mathrm{c}$ \\
FRC permanent & $3.8 \mathrm{a}$ & $3.7 \mathrm{a}$ & $0.09 \mathrm{e}$ & $2.6 \mathrm{~g}$ \\
0.4-mm EFN permanent & $3.1 \mathrm{c}$ & $3.0 \mathrm{c}$ & $0.13 \mathrm{~d}$ & $3.2 \mathrm{f}$ \\
0.9-mm EFN permanent & $2.6 \mathrm{ed}$ & $2.4 \mathrm{~d}$ & $0.19 \mathrm{c}$ & $7.7 \mathrm{~cd}$ \\
FRC opened & $3.4 \mathrm{~b}$ & $3.2 \mathrm{~b}$ & $0.21 \mathrm{c}$ & $5.9 \mathrm{e}$ \\
0.4-mm EFN opened & $3.0 \mathrm{~d}$ & $2.4 \mathrm{~d}$ & $0.24 \mathrm{~b}$ & $7.4 \mathrm{de}$ \\
0.9-mm EFN opened & $2.4 \mathrm{ef}$ & $2.1 \mathrm{e}$ & $0.25 \mathrm{~b}$ & $12.5 \mathrm{~b}$ \\
\hline
\end{tabular}

* Untreated control had no pesticide, treated control was sprayed with pesticides, permanent is where the FRC or EFN were covered throughout except during crop maintenance periods and opened is where the FRC or EFN were opened thrice a week from 9:00 am to 3:00 pm; ** Means followed by the same letter within a column and a variable are not significantly different according to Tukey's honest significant difference (THSD) at $p \leq 0.05$. 
Yield Losses: Use of EFN or FRC significantly reduced yield losses (Tables 2 and 3). The lowest yield reduction was under FRC maintained permanently covered while the highest yield loss was under the untreated control.

\section{Discussion}

Use of EFN and FRC proved beneficial in reducing pest population in tomato production in this study. During the initial stages of tomato growth, weed population was lowest in open field production compared with EFN and FRC covered treatments. Among covered treatments, covers with finer pore diameter (FRC and 0.4-mm EFN) also tended to have more weeds compared with the larger 0.9-mm pore diameter EFN. Within the FRC and each given EFN mesh size, more weeds were noted under covers that were maintained permanently covered compared with those obtained under treatments that were opened thrice a week. According to Aoki [17], higher temperature and soil moisture under covers promotes weed germination and development. Higher weed populations observed under FRC and EFN in the initial stages of tomato growth in the current study could thus be attributed to higher temperature and soil moisture under the covers, which could have favored weed seed germination and seedling growth. However, from the mid to late stages of plant growth, weed populations tended to be lower in FRC and EFN covered treatments than in open field treatments. Weed population under covered treatments similarly depended on the cover pore diameter and whether the covers were maintained permanently covered or opened with the finest pore diameter cover (FRC) maintained permanently covered registered the lowest weed population. Vegetation cover has been reported to smother weeds thus discouraging their growth [18]. Faster growth of tomato plants observed under covered treatments in the current study which could have been favored by the modified microclimate under the covers could possibly have helped in smothering the weeds during the mid through later stages of tomato growth by depriving them of light and nutrients leading to lower weed population.

Considerably reduced populations of leaf miners, cotton bollworms, onion thrips, mites, silver leaf whiteflies, and aphids were also observed under FRC and EFN covered treatments. The cover with the finest pore diameter (FRC) and used permanently had the least number of pests compared to the larger pore diameter (0.9-mm EFN) cover opened thrice a week. Row covers and nets have been documented to offer physical barrier to pests $[4,5,9]$. The use of such covers in the current study may therefore have protected tomato plants from infestations by pests through physical exclusion. In addition, the white nets and floating row covers used could also have offered a visual barrier for flying pests such as leaf miners, onion thrips, moths and silver leaf whiteflies distracting their feeding and mating habits, hence lowering their population under the covered treatments. According to Majumdar [9], cover pore diameter affects entry of insect pests into the crops. This could probably explain the lower population of pests observed under covers with finer pore diameter (FRC and 0.4-mm EFN) compared with those of a larger pore diameter (0.9-mm EFN). In their field tests, Licciardi et al. [8] and Martin et al. [4] similarly observed delayed and reduced aphid infestation on cabbage under netting. Although the incidences of viral diseases were not evaluated in our study, it is likely that use of FRC and EFN could provide significant benefits in the management of such diseases. The reduction of the silverleaf whitefly population noted in the current study could reduce and delay the risk of begomovirus transmission such as tomato yellow leaf curl virus to the plant [6]. 
The main goal of every farmer is to maximize profit. One way of achieving this is through improving yield and quality of crops. Use of FRC and EFN in the current study helped improve tomato yield. At harvest, plants under FRC and EFN covers yielded more total and marketable fruit yields compared with tomatoes grown in the open field. In addition, non-marketable fruit yields and percent yield losses were reduced following the use of FRC and EFN. Non-marketable yield and yield losses tended to increase with increasing cover pore diameter, with the highest non-marketable yields and yield losses obtained under the open field treatments. Within a given cover type, covers maintained permanently closed also resulted in less non-marketable yields and yield losses than those opened thrice a week. Higher infestation on crops from pest and diseases led to non-marketable products [19]. Covering crops physically excludes pest and diseases [4,9]. The lower non-marketable yields and yield losses noted for FRC and EFN covered tomato in the present study could probably have been as a result of the lower pest damage in these treatments. Besides, the modified microclimate (increased air temperature and soil moisture) under covered treatments may also have contributed to improved crop performance and reduced physiological disorders favoring the production of more fruit that met the market standards and less non-marketable fruit. El-Aidy and Sidaros [20] reported higher marketable and less non-marketable yields under protected compared to non-protected tomato. Similarly, Nair and Ngouajio [21] reported more total marketable yield of cucumber (Cucumis sativus L.) under FRC compared with the control.

\section{Conclusions}

The results of this study demonstrate the potential of FRC and EFN especially those of finer mesh size as viable strategies for improving tomato yields through reduction of pest population which can be used alone or as components of integrated pest management. The use of these techniques also stands to reduce the use of pesticides during tomato production leading to healthier produce and a safer environment. Although opening of nets during the day has been recommended by some studies, we recommend permanent use of covers under our research conditions since opening of nets would increase labor requirements with no additional benefit on pest reduction or yield. Net opening has being used in warm climates as a mean to ventilate the crop during hot days. The cool climate and the extra rise in temperature following net cover were actually beneficial for the crop. While the findings of this study provide a good foundation to understanding the influence of EFN and FRC in pest management and tomato performance, further testing of these materials using a wider range of mesh sizes and color, different tomato varieties and in different tomato growing agro ecological zones would be beneficial. An evaluation of the effect of covers on beneficial insects (pollinators and natural enemies) may also be of immense benefit. A full economic analysis factoring in the cost of purchase, installation and management of EFN and FRC will also be useful.

\section{Acknowledgments}

This is part of Master of Science in Horticulture project by Elisha Otieno Gogo of Egerton University, Njoro, Kenya. The study was made possible by the generous support of the American people through the U.S. Agency for International Development (USAID) under Award No. EPP-A-00-09-00004. Additional financial support was provided by Michigan State University and the Centre de coopération 
internationale en recherché agronomique pour le développement (Cirad). The contents are the responsibility of Horticulture Collaborative Research Support Program (HortCRSP) project BioNetAgro investigators and do not necessarily reflect the views of USAID or the U.S. Government. We also acknowledge our project partners, the Kenya Agricultural Research Institute (KARI) and the International Centre of Insect Physiology and Ecology (ICIPE) in Kenya; A to Z Textile Mills in Tanzania; University of Abomey Calavi, Institut National des Recherches Agricoles du Bénin (INRAB), and Association des Personnes Rénovatrices des Technologies Traditionnelles (APPRETECTRA) in Benin for their support.

\section{Conflicts of Interest}

The authors declare no conflict of interest.

\section{References}

1. Ortiz, R.; Hartmann, P. Beyond Crop Technology: The Challenge for African Rural Development; International Institute of Tropical Agriculture (IITA): Ibadan, Nigeria, 2003; p. 46.

2. Abate, T.; van Huis, A.; Ampofo, J.K.O. Pest management strategies in traditional agriculture: An African perspective. Ann. Rev. Entomol. 2000, 45, 631-659.

3. Tumwine, J.; Frinking, H.D.; Jedger, M.J. Integrated cultural control methods for tomato late blight (Phytophthora infestans) in Uganda. Ann. Appl. Biol. 2002, 14, 225-236.

4. Martin, T.; Assogba-Komlan, F.; Houndete, T.; Hougard, J.M.; Chandre, F. Efficacy of mosquito netting for sustainable small holder's cabbage production in Africa. J. Econ. Entomol. 2006, 99, $450-454$.

5. Bextine, B.; Wayadande, A. Effect of insect exclusion on the incidence of yellow vine disease and of the associated bacterium in squash. Plant Dis. 2001, 85, 875-878.

6. Berlinger, M.J.; Taylor, R.A.J.; Lebiush-Mordechi, S.; Shalhevet, S.; Spharim, I. Efficiency of insect exclusion screens for preventing whitefly transmission of tomato yellow leaf curl virus of tomatoes in Israel. Bull. Entomol. Res. 2002, 92, 367-373.

7. Boisclair, J.; Bernard, E. Insect pest management in organic agriculture: Acting in harmony with complexity. Phytoprotection 2006, 87, 83-90.

8. Licciardi, S.; Assogba-Komlan, F.; Sidick, I.; Chandre, F.; Hougard, J.M.; Martin, T. A temporary tunnel screen as an eco-friendly method for small-scale farmers to protect cabbage crops in Benin. Intl. J. Trop. Insect Sci. 2007, 27, 152-158.

9. Majumdar, A. Large-Scale Net-House for Vegetable Production: Pest Management Successes and Challenges for a New Technology; Alabama Cooperative Extension System: Auburn, AL, USA, 2010; p. 350.

10. Waterer, D.; Bantle, J.; Leray, K. Plant Growth Control by Photoselective Filters; Saskatchewan Agriculture and Food University of Saskatchewan: Saskatoon, SK, Canada, 2001; p. 200.

11. Shahak. Y.; Gussakovsky, E.E.; Gal, E.; Ganelevin, R. ColorNets: Crop protection and light quality manipulation in one technology. ISHS Acta Horticult. 2004, 659, 143-151. 
12. Gogo, E.O.; Saidi, M.; Itulya, F.M.; Martin, T.; Ngouajio, M. Microclimate modification using eco-friendly nets for high quality tomato transplant production by small-scale farmers in East Africa. HortTechnology 2012, 22, 292-298.

13. Muleke, E.M.; Saidi, M.; Itulya, F.M.; Martin, T.; Ngouajio, M. The assessment of the use of eco-friendly nets to ensure sustainable cabbage seedling production in Africa. Agronomy 2013, 3, $1-12$.

14. Joubert, G.; Poissonie, J. Tomatoes: Production under nets. Infos-Paris 1991, 69, 37-42.

15. Kassilly, F.N. The fence as a moderator of wildlife menace in Kenya. Afr. J. Ecol. 2002, 40, 407-409.

16. Naika, S.; de Jeude, J.; de Goffau, M.; Hilmi, M.; van Dam, B. Cultivation of Tomato: Production, Processing and Marketing; Agromisa Foundation and CTA: Wageningen, The Netherlands, 2005; p. 91.

17. Aoki, H. Present and future protected horticulture of vegetables. Faming Japan. 1995, 29, $20-24$.

18. Gordon, G.G. Effects of Color Plastic Mulches and Row Covers on the Growth and Production of Okra and Summer Squash. Master's Thesis, Auburn University, Auburn, AL, USA, May 2006.

19. Gaye, M.M.; Maurer, A.R. Modified transplant production techniques to increase yield and improve earliness of brussels sprouts. J. Am. Soc. Hortcult. Sci. 1991, 116, 210-214.

20. El-Aidy, F.; Sidaros, S.A. The effect of protected tomato seedling on growth and yield of late summer tomato in Egypt. Cah. Options Mediterr. 1996, 31, 385-389.

21. Nair, A.; Ngouajio, M. Integrating row covers and soil amendments for organic cucumber production: Implications on crop growth, yield, and microclimate. HortScience 2010, 45, 566-574.

(C) 2014 by the authors; licensee MDPI, Basel, Switzerland. This article is an open access article distributed under the terms and conditions of the Creative Commons Attribution license (http://creativecommons.org/licenses/by/3.0/). 